\title{
Pozzolanic benefit of fly ash and steel slag blends in the development of uniaxial compressive strength of lime stabilized soil
}

\author{
Beneficio puzolánico de las mezclas de cenizas volantes y de escoria \\ de acero en el desarrollo de la resistencia a la compresión uniaxial del \\ suelo estabilizado con cal
}

\begin{abstract}
Benefício pozolânico das misturas de cinzas volantes e de escória de aço no desenvolvimento da resistência à compressão uniaxial do solo estabilizado com cal
\end{abstract}

Fecha de recepción: 4 de junio de 2018

Fecha de aprobación: 25 de julio de 2018
Jijo James*

Ebenezer Paul Billy Graham David ${ }^{*}$ Mahalakshmi Nagarathinam ${ }^{* *+}$ Mohan Kumar Thaniyarasu ${ }^{\text {t*to }}$ Jayapal Madhu

\begin{abstract}
This investigation involved the examination of pozzolanic benefits that resulted from the amendment of lime stabilization of a soil by using a combination of two industrial wastes viz. Fly ash (FA) and Steel Slag (SS). Two lime contents $(6 \%$ and $8 \%$ ), which represented the control specimens, were selected for stabilizing the soil, one above the Initial Consumption of Lime (ICL) and the other above the Optimum Lime Content (OLC), respectively. The lime to total solid waste ratio was maintained as 1:1, and the FA/SS ratio varied within the total solid waste content adopted for amending lime stabilization. The unconfined compressive strength (UCS) of the stabilized samples were determined by casting UCS specimens of $38 \mathrm{~mm}$ x $76 \mathrm{~mm}$ and cured for 2 hours, 7, 14 and 28 days. After curing, the specimens were strained until failure, to study the pozzolanic benefits of adding FA-SS. The results revealed that the addition of FA and SS improved the pozzolanic strength, ranging from 3.5\% to $15 \%$. The optimal dosage of FA and SS also varied with the lime content adopted. For the $6 \%$ lime content, a FA/SS ratio of 1:1 was found to be optimal, whereas for the $8 \%$ lime content, a FA/SS ratio of 3:1 was found to develop the maximum strength. The amendment of lime stabilization with FA/SS clearly brought about the difference in lime stabilization stages, unseen when only lime was adopted as stabilizer.
\end{abstract}

Keywords: ash; blends; lime; slag; soil; strength.

\footnotetext{
* Ph. D. Associate Professor in Civil Engineering. SSN College of Engineering (Tamil Nadu, India).. jijoj@ssn.edu.in. ORCID: 0000-0002-1167-8066.

** Tagore Engineering College (Chennai, India).

*** Tagore Engineering College (Chennai, India).

$* * * *$ Tagore Engineering College (Chennai, India).

$* * * * *$ Tagore Engineering College (Chennai, India).
} 


\section{Resumen}

La investigación examinó los beneficios puzolánicos logrados debido a la modificación de la estabilización con cal de un suelo mediante el uso de una combinación de dos desechos industriales: el Flyash (FA) y el Steel Slag (SS). Se seleccionaron dos contenidos de cal de $6 \%$ y $8 \%$ para estabilizar el suelo; uno por encima del Consumo Inicial de Cal (ICL) y el otro por encima del Contenido Óptimo de Cal (OLC), respectivamente; estos formaron las muestras de control para determinar el efecto de los desechos sólidos sobre la estabilización con cal. La relación cal-residuos sólidos totales se mantuvo en 1:1 y la relación FA-SS varió dentro del contenido total de desechos sólidos adoptado para la modificación de la estabilización con cal. La resistencia a la compresión no confinada (UCS) de las muestras estabilizadas se determinó mediante moldeo de muestras UCS de 38 x 76 mm y se curó durante 2 horas, 7, 14 y 28 días. Las muestras después del curado se tensaron hasta que el estudio de los beneficios puzolánicos de la enmienda FA-SS se hizo imposible. Los resultados de la investigación revelaron que la adición de FA y SS benefició la fuerza puzolánica entre el 3,5 \% y el $15 \%$. El contenido óptimo de la dosificación FA y SS también varió con el contenido de cal adoptado. Para un contenido de cal del $6 \%$, se encontró que la relación FA/SS de 1:1 fue la más óptima, mientras que para el contenido de cal del $8 \%$ se encontró que la relación FA/ SS de 3:1 desarrolló la resistencia máxima. También se encontró que la modificación de la estabilización con cal utilizando FA/SS provocó, claramente, diferencias en las etapas de estabilización que no se observaron cuando solo se adoptó la cal como estabilizador.

Palabras clave: cal; cenizas; escoria; mezclas; resistencia; suelo.

\section{Resumo}

A pesquisa examinou os benefícios pozolânicos logrados devido à modificação da estabilização com cal de um solo mediante o uso de uma combinação de dois dejetos industriais: o Flyash (FA) e o Steel Slag (SS). Selecionaramse dois conteúdos de cal de 6\% e 8\% para estabilizar o solo; um acima do Consumo Inicial de Cal (ICL) e o outro acima do Conteúdo Ótimo de Cal (OLC), respectivamente; estes formaram as amostras de controle para determinar o efeito dos dejetos sólidos sobre a estabilização com cal. A relação cal-resíduos sólidos totais se manteve em 1:1 e a relação FA-SS variou dentro do conteúdo total de dejetos sólidos adotado para a modificação da estabilização com cal. A resistência à compressão não confinada (UCS) das amostras estabilizadas determinouse mediante moldagem de amostras UCS de $38 \times 76 \mathrm{~mm}$ e curou-se durante 2 horas, 7, 14 e 28 dias. As amostras depois do curado se esticaram até que o estudo dos benefícios pozolânicos da emenda FA-SS fez-se impossível. Os resultados da pesquisa revelaram que a adição de FA e SS beneficiou a força pozolânica entre 3,5\% e 15\%. O conteúdo ótimo da dosagem FA e SS também variou com o conteúdo de cal adotado. Para um conteúdo de cal de $6 \%$, encontrou-se que a relação FA/SS de 1:1 foi a melhor, enquanto que para o conteúdo de cal de $8 \%$ encontrouse que a relação FA/SS de 3:1 desenvolveu a resistência máxima. Também se encontrou que a modificação da estabilização com cal utilizando FA/SS provocou, claramente, diferenças nas etapas de estabilização que não se observaram quando só se adotou a cal como estabilizador.

Palavras chave: cal; cinzas; escória; misturas; resistência; solo.

\section{Cómo citar este artículo:}

J. James, E. P. B. Graham David, M. Nagarathinam, M. K. Thaniyarasu, and J. Madhu, "Pozzolanic benefit of fly ash and steel slag blends in the development of uniaxial compressive strength of lime stabilized soil," Revista Facultad de Ingenieria, vol. 27 (49), pp. 7-21, Sep. 2018. 


\section{INTRODUCTION}

Pozzolanic reactions are indispensable in the development of strength of lime stabilized soils, which predominantly depend on the progress of such reactions that result in the formation of cemented products responsible for developing strength. Pozzolanic reactions depend on the curing period and require extended periods for the reactions to proceed to gain significant strength. Pozzolanic reactions involve the reaction between soluble silica and soluble alumina in the soil with calcium from lime in a high $\mathrm{pH}$ environment that ensures the solubility of the silica and alumina. Pozzolanic reactions continue as long as enough calcium is available and the $\mathrm{pH}$ is high enough to maintain the solubility of the silica and alumina. A pozzolan can be defined as a fine material of siliceous and aluminous composition, which forms cemented products in the presence of water and calcium hydroxide [1]. Clay is a pozzolan as it supplies the silica and alumina for the pozzolanic reactions. However, certain soils lack sufficient silica and alumina, which decrease rapidly after the pozzolanic reaction starts, slowing down the reaction due to lack of raw materials. This results in the formation of very less cemented products, reflected in the low strength of the stabilized soil. Under such situations, adding external pozzolanic agents to the soil as auxiliary additives can augment the supply of silica and alumina, allowing the reaction to proceed longer, and, therefore, increase the development of strength. Industrial and agricultural solid wastes have long been the source for silica and alumina in such reactions, in both concrete and soil stabilization activities. Numerous researchers have worked on the utilization of different solid wastes as pozzolans in soil stabilization. Fly ash (FA) [2, 3], rice husk ash $[4,5]$, ground granulated blast furnace slag $[6,7]$, phosphogypsum $[8,9]$, bagasse ash $[10$, 11], waste paper sludge ash [12], press mud [13, 14], red mud $[15,16]$ and egg shell ash $[15,17]$ are some of the materials that have been used as pozzolans in lime stabilization of soils. It has been found that using industrial solid wastes as auxiliary additives to cement/ lime stabilization further improves the stabilization process [18]. Generally, a waste material is added in varying combinations as pozzolan to the primary binder. However, in this investigation, combinations of two industrial wastes viz. FA and Steel slag (SS) were used as pozzolans to lime in stabilization of soil. Both solid wastes are produced in high quantities around the world, and their reutilization in soil stabilization will result in pozzolanic strength benefits, as well as environmental benefit of waste management. The worldwide production of coal combustion products, including FA, stands at a whopping 780 million tons as of 2010 [19]; the SS generation around the world stands at 350 million tons [20]. In India, FA generation stands at 184.14 million tons as of 2015 [21], whereas the generation of steel slag stands at 12 million tons [22]. FA usage in stabilization of soil with lime has been reported extensively in the literature. SS is another industrial waste with applications in soil stabilization. SS has been used very effectively in civil engineering like in the manufacture of cement [23], mortars [24], road base material [25], immobilization of heavy metals [26] and soil improvement [27]. In earlier works, SS has been predominantly used as a standalone stabilizer in soil stabilization. This work aimed at studying the pozzolanic benefits achieved due to the amendment of lime stabilization by adding two industrial solid wastes viz. FA and SS.

\section{Materials And Methods}

The various materials that were used in this investigation include the soil that needed to be stabilized, the lime adopted as the primary stabilizer, and the two solid wastes, FA and SS.

\section{A. Virgin soil}

The virgin soil adopted in this study was collected from Thiruvallur district of Tamil Nadu, India. The soil was dark in color with a very high natural water content. The soil exhibited a shiny surface when cut, indicating very fine particle size. The soil was prepared in accordance with BIS (Bureau of Indian Standards) code and its geotechnical properties were characterized in the laboratory. Table 1 shows the properties of the soil determined in a previous investigation [9]. 
TABLe 1

PROPERTIES OF THE SOIL

\begin{tabular}{lc}
\hline Property & Value \\
\hline Liquid Limit & $68 \%$ \\
\hline Plastic Limit & $27 \%$ \\
\hline Plasticity Index & $41 \%$ \\
\hline Shrinkage Limit & $10 \%$ \\
\hline Specific Gravity & 2.76 \\
\hline \%Gravel & 0 \\
\hline \%Sand & 2.5 \\
\hline \%Silt & 60.5 \\
\hline \%Clay & 37 \\
\hline Maximum Dry Density & $15.3 \mathrm{kN} / \mathrm{m}^{3}$ \\
\hline Optimum Moisture Content & $25 \%$ \\
\hline UCS & $115.8 \mathrm{kPa}$ \\
\hline pH & 6.53 \\
\hline Soil classification & $\mathrm{CH}$
\end{tabular}

\section{B. Lime}

Hydrated laboratory grade lime was used in this investigation for stabilizing the soil, obtained from M/s. Loba Chemie Pvt. Ltd. Laboratory grade lime was adopted to reduce variations in the test results due to consistency in its composition. Table 2 summarizes the chemical composition of the lime as given by the manufacturer.
TABLE 2

Composition OF LIME

\begin{tabular}{lr}
\hline Component & Content \\
\hline Assay & $90 \%$ \\
\hline Chloride & $0.04 \% \mathrm{Max}$ \\
\hline Sulphate & $0.4 \% \mathrm{Max}$ \\
\hline Arsenic & $0.0004 \% \mathrm{Max}$ \\
\hline Lead & $0.004 \% \mathrm{Max}$ \\
\hline Insoluble Matter & $1 \% \mathrm{Max}$ \\
\hline
\end{tabular}

\section{Flyash}

FA is a by-product of the combustion of coal during power generation in thermal power plants. It is one of the largest industrial by-product wastes in India, so much so that the Government of India leads the FA reutilization efforts for effective waste management. In India, the utilization of FA has steadily increased from 6.64 million tons in 1996-97 to 102.54 million tons in 2014-15 [21]. Its utilization in soil engineering has also increased over the years. Figure 1 shows the use of FA in soil engineering, including roads and embankments and reclamation of low lying areas. FA has been extensively adopted in various soil engineering applications like soil stabilization, stabilized soil blocks, as subgrade material and in fill applications. The cementitious property of FA is not comparable to that of lime, however, in the presence of an activator, it can produce cementitious products that can enhance the strength of the amended soil. The FA used in this work was class F type FA, obtained from Agni Steels Pvt. Ltd., Perundurai, Tamil Nadu, India. The FA was sieved through a 75-micron BIS sieve for removing lumps, and the fine fraction that passed through the sieve was adopted in the investigation. 


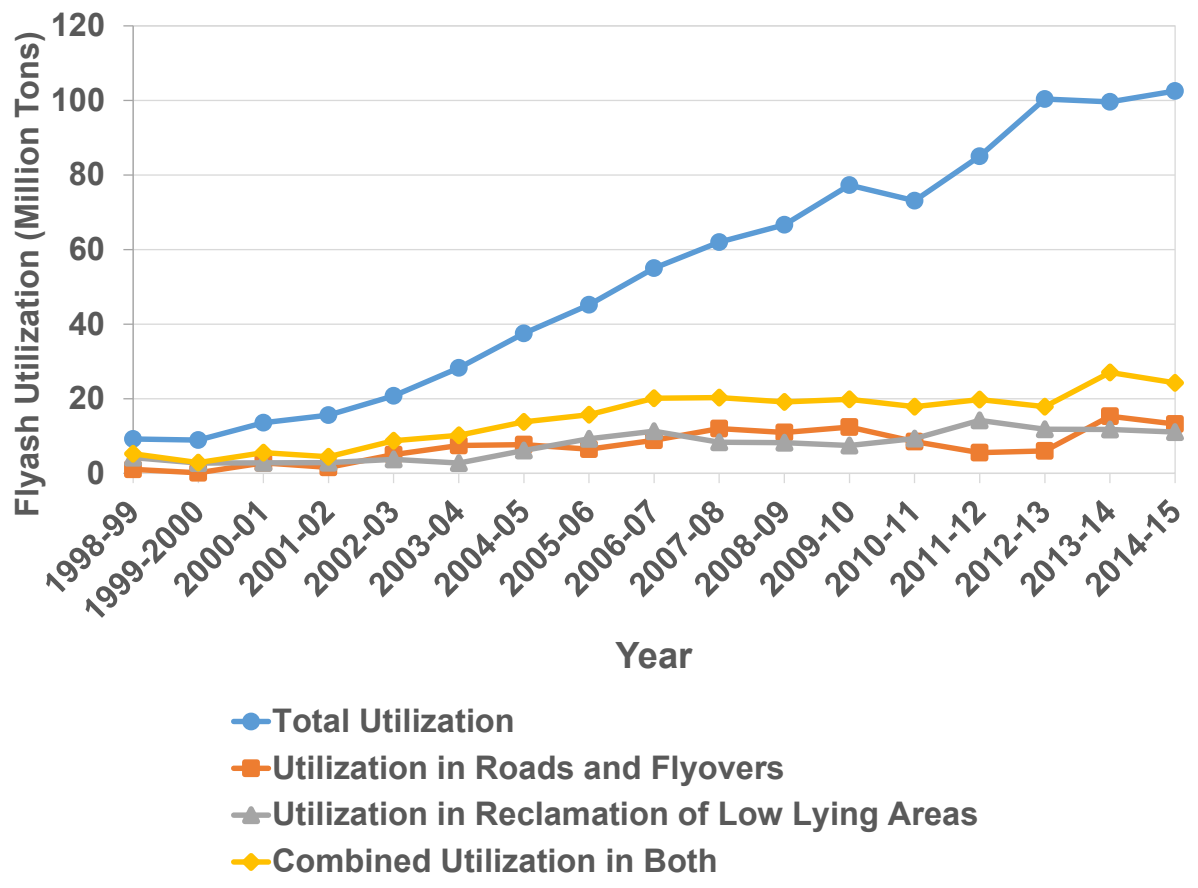

Fig. 1. Utilization of FA in soil engineering [18].

\section{Steel Slag}

Steel slag is a by-product of the steel industry, produced during the separation of molten steel from the impurities in the furnace. The slag occurs as a molten liquid floating on top of the molten steel as scum, and is a complex mixture of silicates and oxides that hardens upon cooling. Steel slag is rich in silica, alumina, iron oxide and calcium oxide. It has applications in various areas of civil engineering, like manufacture of cement [23], mortar [24], road base material [25], immobilization of heavy metals [26] and soil improvement [27]. Crushed steel slag has a granular nature and can contribute to increase the friction component of a soil amended with steel slag. Chen et al. [24] adopted steel slag as a replacement for fine aggregates in cement mortar, whereas Liang et al. [27] noticed an increase in the friction angle of clayey soil when increasing the steel slag and water content. Thus, it is evident from the chemical composition and earlier literature that steel slag is capable of interacting both chemically and physically with the soil, modifying its properties, which prompted its consideration in this investigation. The steel slag used in this study was obtained from Messrs. Agni Steels Pvt. Ltd., Perundurai, Tamil Nadu, India.

\section{E. Methodology}

The methodology involved the preparation of soil [28], followed by its geotechnical characterization and classification [29], all in accordance with relevant BIS codes. Subsequently, the lime contents for soil stabilization were determined. According to Nasrizar et al. [30], there are three phases in the relationship between lime content and strength viz. below Initial Consumption of Lime (ICL), between ICL and Optimum Lime Content (OLC) and above OLC. Based on this work, the ICL of the soil was determined using the Eades and Grim $\mathrm{pH}$ test [31], according to the ASTM code D6276 [32], whereas the OLC was determined using the procedure suggested by Thompson [33]. After obtaining the ICL and OLC, two lime contents were adopted, one in the stage between ICL and OLC, and the other above OLC for stabilization of the soil. The lime stabilized soil was amended with an equal content of pozzolanic additive (FA and SS), and the effect of the pozzolanic amendment was studied. The combinations of FA and SS were varied within the total content of the pozzolan. The variations in FA and SS contents were selected at random. The UCS samples were prepared to a density of $14.72 \mathrm{kN} / \mathrm{m}^{3}$ at a water content of $25 \%$ in a split mold of $38 \mathrm{~mm} \times 76 \mathrm{~mm}$ under static compaction. All 
samples were prepared to the same density and water content. Similar procedure was followed by earlier researchers $[6,9,34]$. After molding, the samples were ejected and immediately placed in sealable polythene covers for curing without losing moisture. The samples were cured for periods of 0 ( 2 hours), 7 , 14 and 28 days for studying the immediate, early and delayed strength of the samples. ASTM recommends curing periods of 7, 28 and 90 days [35]. At the end of the specified curing periods, the samples were strained axially at a rate of $0.625 \mathrm{~mm} / \mathrm{min}$ until failure.

\section{Results ANd Discussion}

The minimum lime content required to raise the $\mathrm{pH}$ of the stabilized soil to 12.4 is called the ICL for a given soil [32]. The ICL determined from the Eades and Grim $\mathrm{pH}$ test was $5.5 \%$. The lime content that produces the maximum strength of the stabilized soil is called the OLC. The OLC was determined as 7\%. Based on these two boundaries, two lime contents, one between ICL and OLC (6\%) and one above OLC $(8 \%)$ were chosen for soil stabilization. Based on these two contents, an equal amount of pozzolanic additives of FA and SS were added along with lime for amending the stabilization of the soil. Table 3 shows the combinations of lime, FA and SS adopted in this investigation.

TABLE 3

STABILIZER AND POZZOLAN COMBINATIONS

\begin{tabular}{c|c|c|c}
\hline Lime (\%) & FA (\%) & SS (\%) & Notation \\
\hline \multirow{4}{*}{6} & 0 & 0 & L6FA0SS0 \\
\cline { 2 - 4 } & 2 & 4 & L6FA2SS4 \\
\cline { 2 - 4 } & 3 & 3 & L6FA3SS3 \\
\cline { 2 - 4 } & 4 & 2 & L6FA4SS2 \\
\hline \multirow{4}{*}{8} & 0 & 0 & L8FA0SS0 \\
\cline { 2 - 4 } & 2 & 6 & L8FA2SS6 \\
\cline { 2 - 4 } & 4 & 4 & L8FA4SS4 \\
\cline { 2 - 4 } & 6 & 2 & L8FA6SS2 \\
\hline
\end{tabular}

\section{A. Uniaxial strength of amended lime stabilized soil}

Adding FA and SS to lime stabilization of an expansive soil, modified the development of strength of the $6 \%$ lime stabilized soil (Fig. 2).

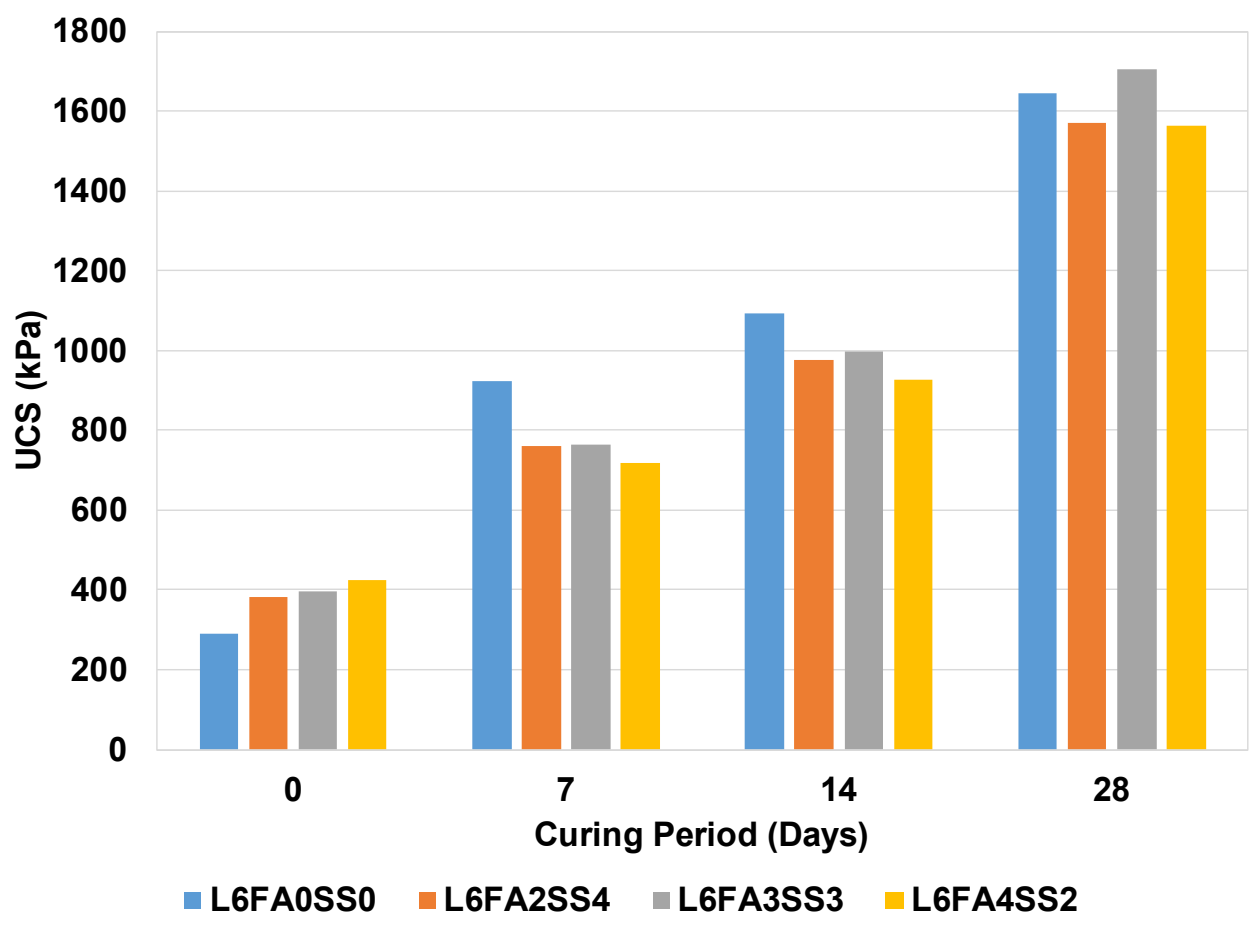

Fig. 2. Effect of FA and SS amendment on $6 \%$ lime stabilized soil. 
The immediate strength of the stabilized soil increased in all the three combinations of FA and SS investigated (Fig. 2). The maximum increase in strength was achieved by the L6FA4SS2 combination at 2 hours of curing. The immediate strength of lime stabilized soil increased from $289.09 \mathrm{kPa}$ to $425.25 \mathrm{kPa}$. However, the immediate gain in strength was not sustained at early curing period of 7 days. It is clear that none of the combinations were capable of producing strength higher than pure lime stabilized soil. The trends of strength gain among the three combinations also changed with L6FA3SS3, producing the highest strength of the three combinations at 7 days of curing. The strength of the combination was $754.22 \mathrm{kPa}$ against $990.58 \mathrm{kPa}$ for pure lime stabilized soil. Thus, none of the combinations were capable of augmenting the early strength of the stabilized soil. At 14 days of curing, the trends of the strength development were similar but with clearer differences in strength among the three combinations. But, the strengths remained lower than pure lime stabilized soil, though the difference between the strength of pure lime stabilized soil and the pozzolan amended lime stabilized soil decreased at 14 days of curing. The strength of L6FA3SS3 was $996.59 \mathrm{kPa}$ against $1092.57 \mathrm{kPa}$ produced by $6 \%$ lime stabilized soil. At 28 days of curing, L6FA3SS3 was the only combination that produced a strength $(1705.025 \mathrm{kPa})$ higher than that of pure lime stabilized soil $(1646.157 \mathrm{kPa})$. Thus, the pozzolanic benefit of adding FA and SS to lime content slightly higher than ICL was only visible after a delayed curing time of 28 days, though still marginal in comparison with pure lime stabilized soil. The delayed gain in strength may be attributed to the coarser steel slag particles, which may have taken a longer time to dissolve and contribute to the pozzolanic reaction, thus slowing down the rate of progress of the reaction.

Figure 3 shows the pozzolanic effect of adding FA and SS to the $8 \%$ lime stabilized soil. Similar to the
$6 \%$ lime stabilization, there was an increase in the immediate strength of the stabilized soil due to FA and SS amendment of the soil. The maximum increase in strength was produced by the L8FA4SS4 combination with $437.35 \mathrm{kPa}$ against $357.07 \mathrm{kPa}$ for pure $8 \%$ lime stabilized soil. The trends in early strength, at 7 and 14 days of curing, were similar to that of the $6 \%$ lime stabilized soil, wherein none of the combinations produced strength higher than pure lime stabilized soil. However, the strength development of the pozzolan amended combination showed a transition during this period. The strength development of combinations L8FA2SS4 and L8FA6SS2 caught up with that of L8FA4SS4 by 14 days of curing; therefore, the variations among them were marginal. However, in the following 14 days of curing, the two former combinations overtook the strength development of the latter. The combination L8FA6SS2 produced a maximum strength of $1904.33 \mathrm{kPa}$ against 1653.877 $\mathrm{kPa}$ of pure $8 \%$ lime stabilized soil. The next highest strength was gained by the L8FA2SS4 combination with a strength of $1839.23 \mathrm{kPa}$.

However, this was a surprising result so that a clear understanding of the contribution of FA or SS could not be achieved. A steady increase in strength resulting from combinations with either FA/SS content or equal ratio blend would have been easy to interpret regarding the contributory effects of the pozzolan. However, although the maximum strength obtained with L8FA6SS2 indicates that FA is the major contributor, the next highest strength gained by L8FA2SS6 contradicts it by indicating that $\mathrm{SS}$ is the major contributor. The equal ratio blend produced the lowest strengths of all three combinations. Thus, complex interactions among the three components and the soil are responsible for the results obtained. This needs a more detailed investigation at the micro level, studying the mineralogy and microstructure of the stabilized soil specimens. 


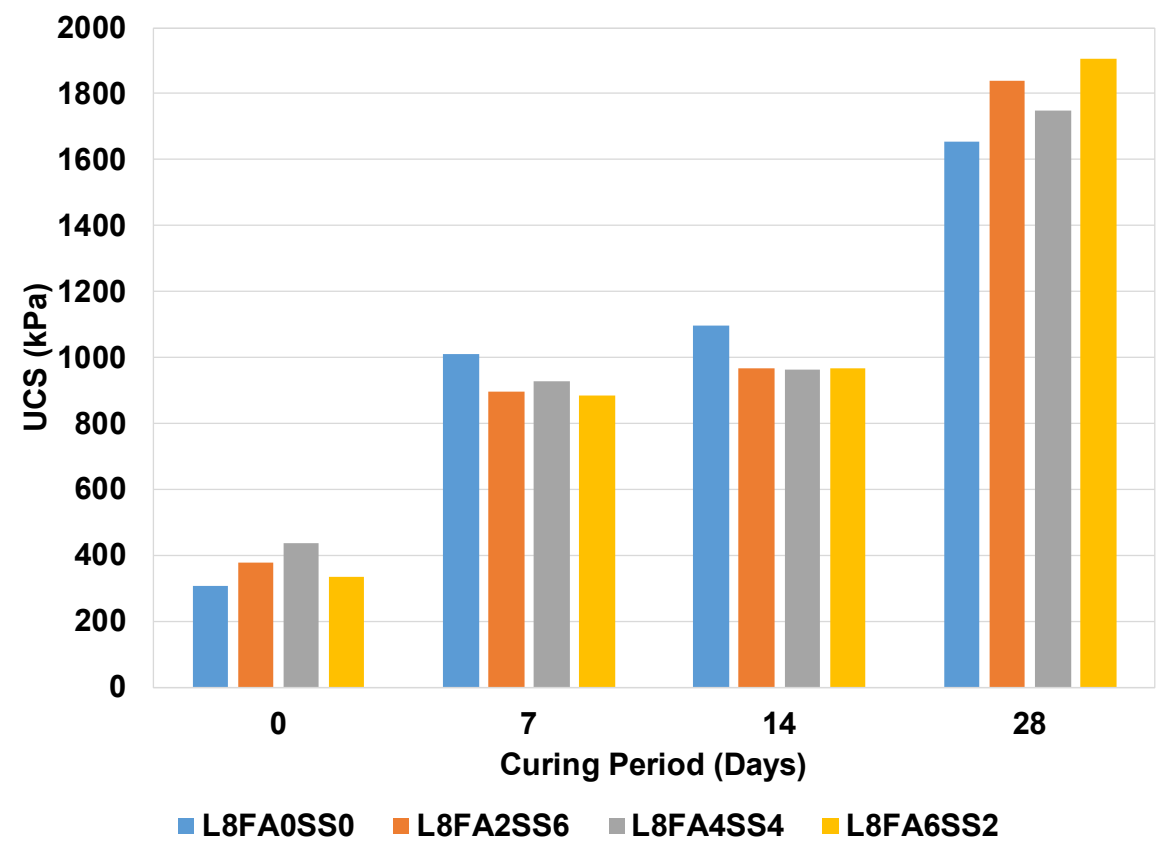

Fig. 3. Effect of FA and SS Amendment on 8\% Lime Stabilized Soil.

\section{B. Percentage strength gain}

To better understand the pozzolanic benefit of adding FA and SS to lime stabilized soil, a percentage strength gain analysis was performed. Similar analyses have been performed by earlier researchers [36, 37]. The calculations were done by measuring the gain in strength of the pure lime stabilized soil (control) after amending it with solid wastes. Figure 4 shows the percentage strength gained with the three FA and SS combinations. The gained strength for both lime contents $(6 \%$ and $8 \%)$ showed contrasting results, with the equal blend ratio producing the maximum gained strength at $6 \%$ and the lowest gained strength at $8 \%$. At $6 \%$ lime stabilization, only the L6FA3SS3 combination produced a strength gain of $3.57 \%$, whereas the other two combinations resulted in a strength loss of around 5\%. In contrast, at $8 \%$ lime stabilization, the same combination produced the lowest gained strength $(5.72 \%)$, whereas the other two combinations, L8FA2SS6 and L8FA6SS2, produced strength gains of $11.2 \%$ and $15.1 \%$, respectively. It is clear that the relationship between development of strength and lime content is different in the zone between ICL and OLC (6\% lime) and above OLC (8\% lime) lime as found by Nasrizar et al. [30]. However, the difference is that the trends are seen here in a limepozzolan stabilization of expansive soil. A previous investigation, did not find contrasting trends in lime stabilization amended with Phosphogypsum (PG) as additive, but stabilized at ICL and OLC; in addition, both lime contents showed an increase in strength with increase in PG content [9]. 


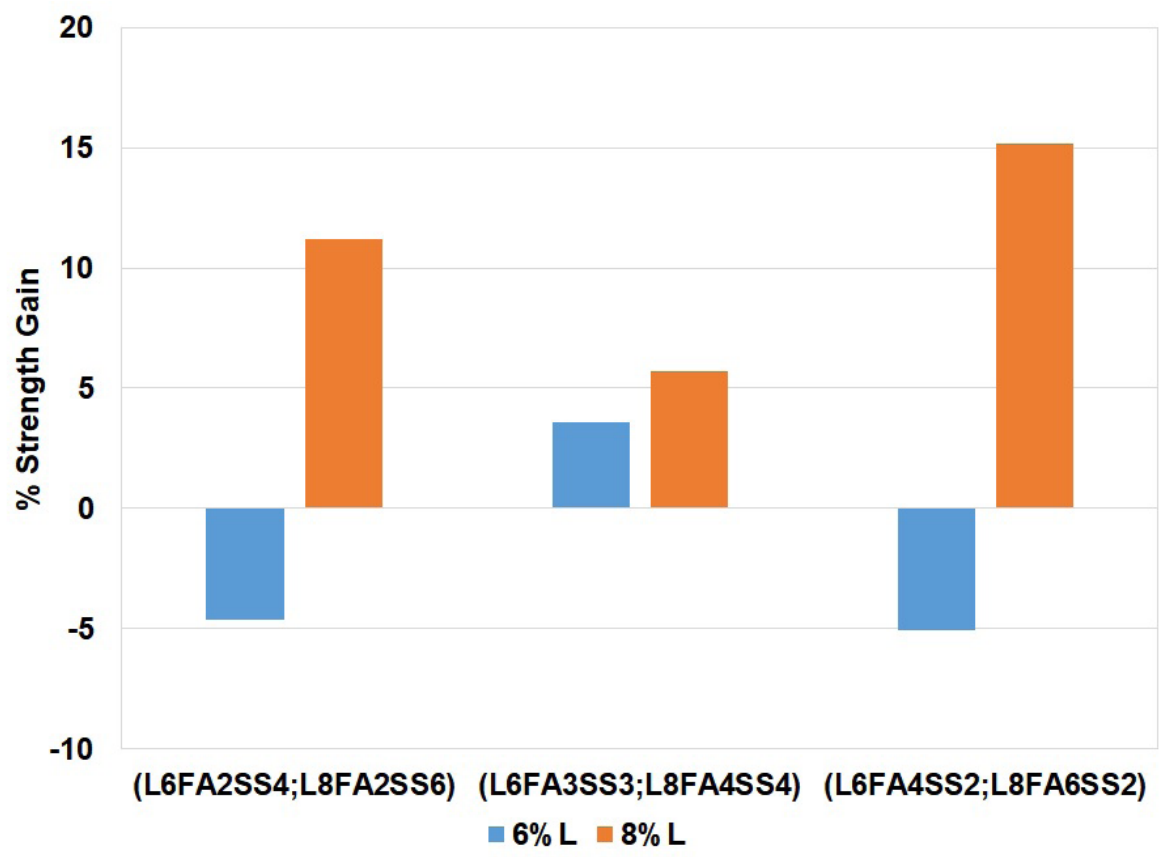

Fig. 4. Percentage strength gain of FA and SS amended lime stabilized soil.

\section{Effect of curing on the development of strength}

To study the development of strength of lime stabilized soil with curing, the optimal combinations L6FA3SS3 and L8FA6SS2 were analyzed. In general, the strength of the lime stabilized soil sample increased with curing, regardless of the amendment with FA and SS (Fig. 5). This agrees with the results reported by earlier researchers $[9,38-40]$, wherein increasing curing increased the strength of lime stabilization. Approximately $50 \%$ of the strength of the lime stabilized soil was developed within the first 7 days of curing (Fig. 5), which agrees with Bell [38]. However, here, the same result was found for the amended lime stabilized specimens modified with FA and SS. In contrast, Bhuvaneshwari et al. [36] reported that $50 \%$ of the strength of lime stabilized soil was achieved within the first 3 days of curing. The second observation is the lack of major differences between the strength of L6FA0SS0 and that of L8FA0SS0 (Fig. 5), despite they belong to two different phases of lime stabilization [30]. A possible explanation is that increasing lime content beyond ICL increases strength until OLC, beyond this, the strength of the stabilized soil decreases. Perhaps, the choice of lime contents adopted in this investigation was such that they were on the opposite sides of OLC but produced similar strength: one in the zone of strength increase, and the other in the zone of strength decrease. This can be compared to similar densities being achieved, one on the dry side of optimum and the other on the wet side of optimum in the moisture density relationship curves. Finally, the development of strength between days 7 and 14 slowed down slightly, which is rare and, therefore, needs further probing in future investigations; beyond 14 days of curing, there was a rapid gain in strength. 


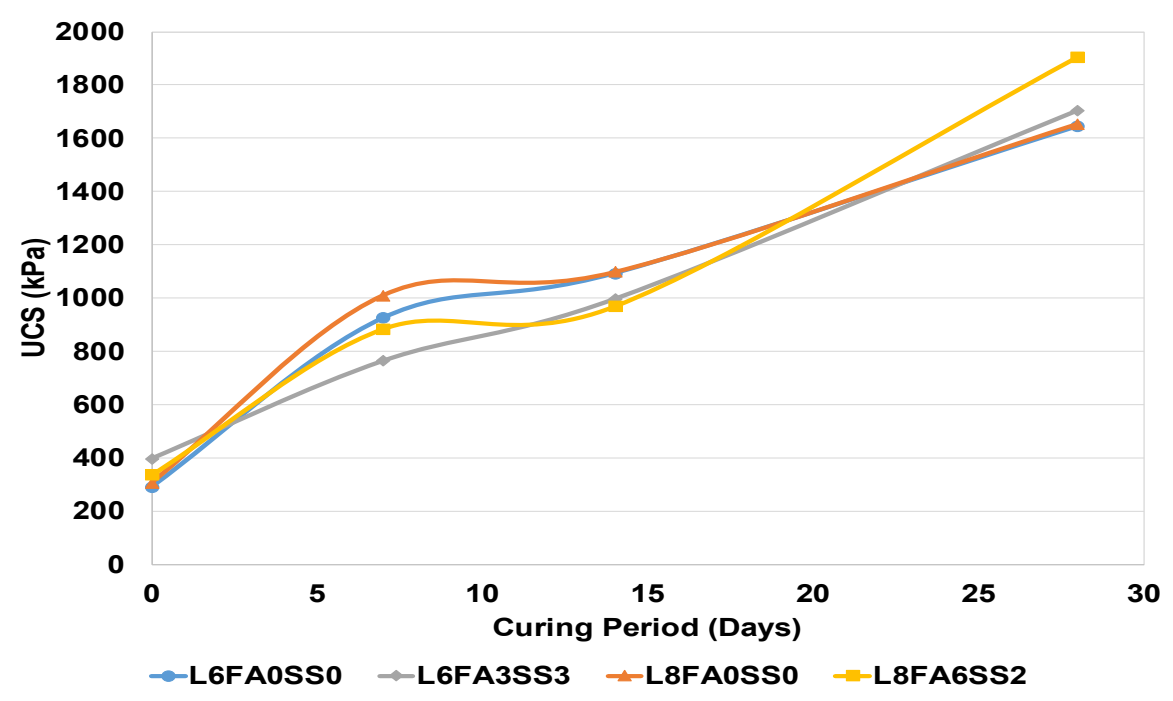

Fig. 5. Development of strength of optimal combinations with curing.

The third significant observation is that the amendment of lime stabilization using solid wastes produced the difference in the lime stabilization stages below OLC and above OLC. The strength development of the two lime stabilized soils were similar as stated earlier when only lime was used for stabilization. However, amending the stabilization process with a combination of FA and SS resulted in strength differences, as well as in optimal combinations that produced the maximum strength. For below OLC lime content of $6 \%$, the amendment of the stabilization process resulted in a marginal increase in strength. But, for lime content above OLC, the amendment produced a significant increase in strength at the end of 28 days of curing, as seen from the significant gap between the curves. Then again, the optimal dosages of additives also changed for both cases: for $6 \%$ lime content, the maximum strength was produced when equal doses of FA and SS at 3\% each were added, whereas, for $8 \%$ lime content, $6 \%$ FA and $2 \%$ SS produced the highest strength. Therefore, these results only further reinforce the theory of Nasrizar et al. [30] who suggest the existence of different stages of lime stabilization related to the development of strength.

The fourth significant observation is that the addition of solid wastes influences the development of strength. Adding FA and SS combination results in a slower development of strength (Fig. 5). The strength gain curve of the amended stabilized samples was lower than those of pure lime stabilized soil samples at early curing periods of less than 14 days. Only when a curing period of 28 days is attained, the strengths of the FA/SS amended samples are stronger than the pure lime stabilized soil. Thus, it can be stated that the pozzolanic combination of FA and SS can provide pozzolanic strength benefits, but at a relatively lower pace in terms of strength gain. As mentioned earlier, this may be due to the fact that the coarser steel slag particles take longer to dissolve than the soil particles.

\section{A comparative discussion}

To better understand the results obtained here, we attempted to compare them with previous studies (Figs. 6-8). Earlier researches adopted a combination of FA and SS, whereas we used FA and SS as additives to lime stabilization of soil. In order to bring out the stabilization effects on a comparable level, the modification or improvement in soil strength was expressed as 'Strength Gain Ratio' (SGR), which is expressed as the ratio of modified strength of the soil after stabilization to the strength of the virgin soil. Since we used a combination of lime, FA and SS, we assessed the strength of lime stabilized soil before and after amending it with FA and SS to determine the SGR and thus, gauge the effect of FA and SS. To determine the effect of the two solid wastes, we expressed the total additive dosage used as FA/SS ratio. 


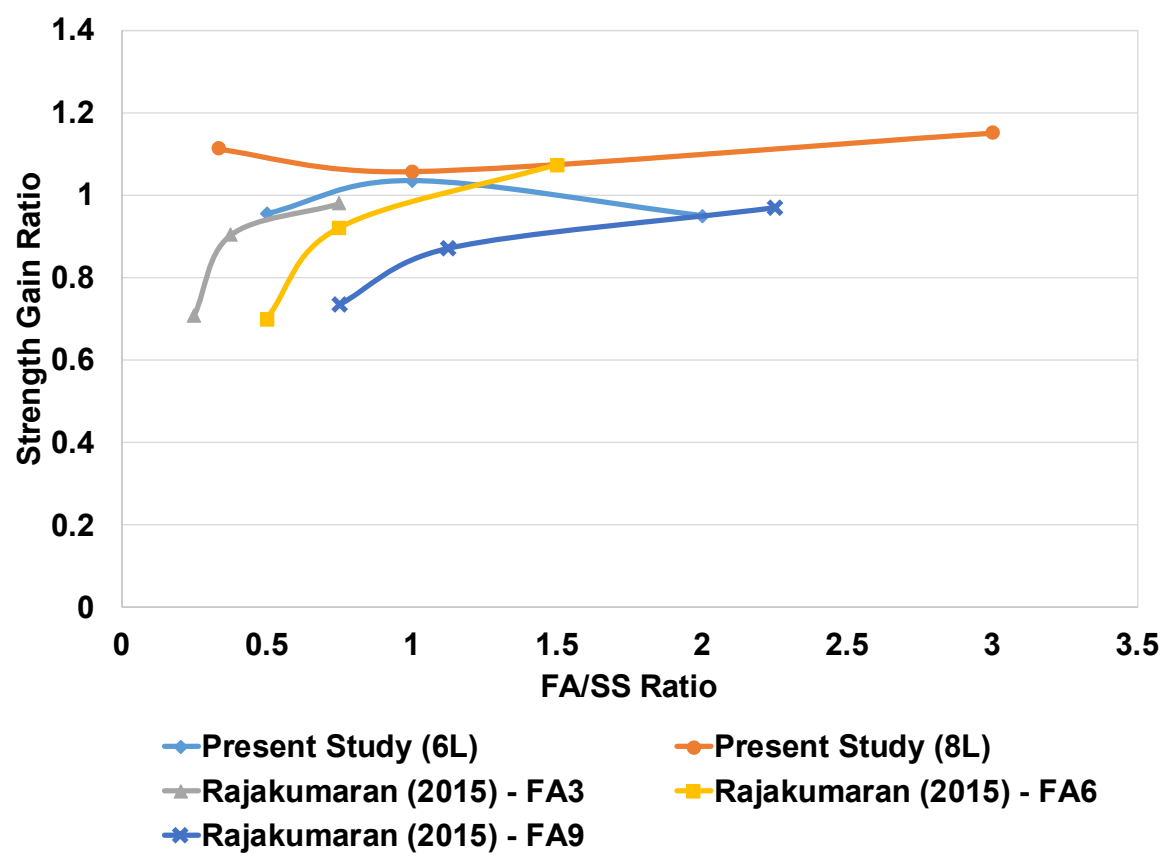

Fig. 6. Comparison of this study with Rajakumaran [41].

Two earlier works by Rajakumaran [41] and Yildirim et al. [42] were used for comparison. These works are compared individually with the present study to avoid confusions and reduce the distortion of the curves due to scaling effects; subsequently, an overall comparison is presented. Comparing this study with Rajakumaran [41] shows that the addition of FA and SS in the present study produced contrasting results: at $6 \%$ lime, the SGR increased at only one particular FA/SS ratio, whereas at $8 \%$ lime, there was an initial decrease in SGR at a FA/SS ratio close to 1, followed by an increase (Fig. 6). For three distinct FA contents, Rajakumaran [41] found a steady increase in the SGR when increasing the FA/SS ratio, with the maximum SGR achieved when FA content was $6 \%$. If the peak values of SGR of the three FA contents were considered a trend, then it shows a similar pattern as that shown by the $6 \%$ lime stabilized soil amended with FA/SS. This may be due to the fact that the three curves of Rajakumaran [41] were based on a fixed FA content with varying SS content. However, in the present study, both FA and SS contents were varied. 


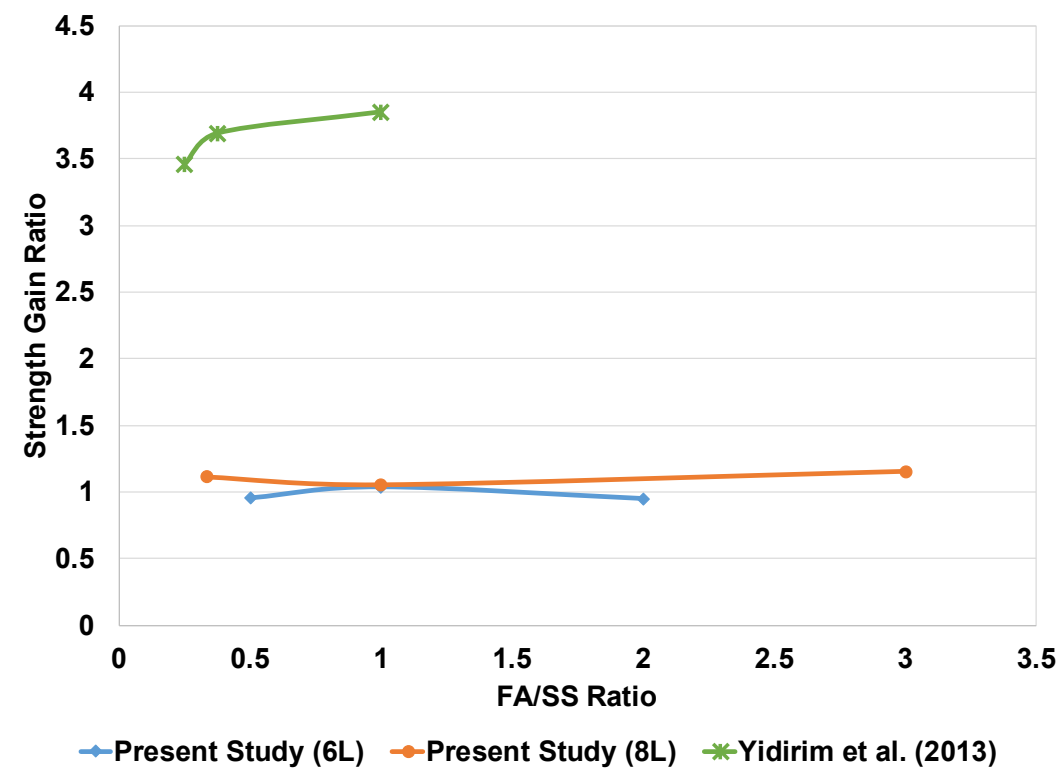

Fig. 7. Comparison of this study with Yildirim et al. [42].

Yildirim et al. [42] achieved a huge SGR compared to the present study (Fig. 7). In addition, they reported, like Rajakumaran [41], an increase in the SGR when increasing the FA/SS ratio. The high SGR achieved by Yildirim et al. [42] may be due to the fact that they adopted class $\mathrm{C}$ type FA in their investigation, whereas both Rajakumaran [41] and we adopted class F type FA. Because class C type FA is cementitious, it could have a better stabilization effect and, hence, a higher SGR. Moreover, in the previous studies, the SGR was derived in relation to the strength of the virgin soil, whereas in the present study, the strength of lime stabilized soil was taken as reference. The strength gained by lime is already high when compared to virgin soil and, hence, the SGR values are lower.

Comparing the three works (Fig. 8), it is seen that irrespective of FA class, the increase in FA/SS ratio led to an increase in SGR. Beyond a FA/SS ratio of 1, the slopes of the curves decline, indicating a reduced rate of increase in SGR.

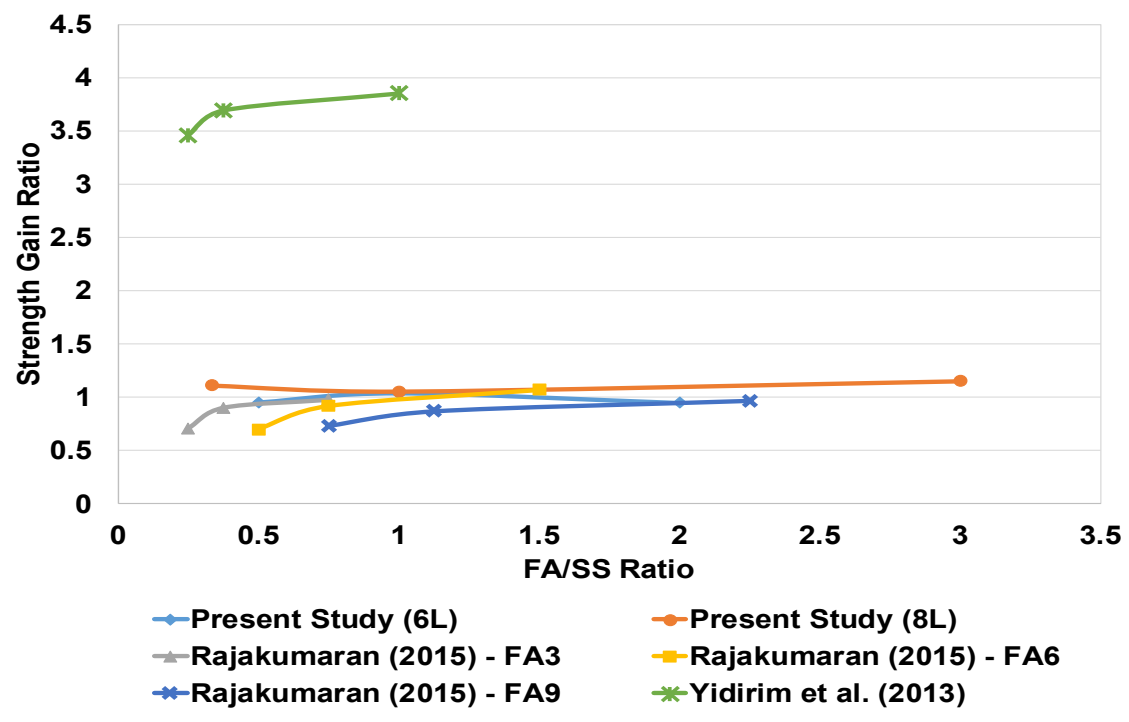

Fig. 8. Comparison of all three investigations. 


\section{Conclusions}

Based on the investigation conducted in stabilizing an expansive soil with lime and a combination of FA and SS, the following points can be concluded.

i. Amendment of lime stabilization of soil with FA and SS can result in pozzolanic strength benefits leading to a gain in strength. A gained strength between $3.5 \%$ and $15 \%$ can be achieved when sufficient lime is available for stabilizing the soil.

ii. Increasing the length of the curing period results in a strength gain of the soil when FA and SS are added during stabilization. Within the first 7 days, $50 \%$ of the strength of the stabilized soil is achieved; however, adding FA and SS retards the rate of strength gain during early curing.

iii. The strength gained due to the addition of FA and SS depends upon the lime content adopted for stabilization. The optimal FA/SS ratio changed from $1: 1$ to $3: 1$ when the lime content changed from $6 \%$ to $8 \%$. Thus, the effects of FA and SS on the development of strength are different for lime contents below and above OLC.

iv. The influence of FA and SS on the strength gain was different compared to previous studies, wherein an increase in the FA/SS ratio resulted in a greater strength gain. A comparison with earlier studies revealed that FA class did not influence the strength gain trend in the present study. Moreover, a FA/SS ratio greater than 1 did not produce much of a benefit in terms of strength gain. However, the above conclusions may be due to the presence of lime in the present study.

The combination ofFA and SS yielded some interesting results in soil stabilization with and without lime; therefore, this is an area that needs more research for achieving better clarity and identifying optimal blends that allow attaining maximum pozzolanic benefits.

\section{Author Contributions}

Jijo James, Ebenezer Paul Billy Graham D. and Mahalakshmi N. conceived the idea for the investigation. Jijo James, Mohan Kumar $\mathrm{T}$. and Jayapal M. designed the experimental program. Ebenezer Paul Billy Graham D., Mahalakshmi N.,
Mohan Kumar T. and Jayapal M. carried out the laboratory investigations. Jijo James, Ebenezer Paul Billy Graham D. and Mahalakshmi N. analyzed the data and interpreted the results. Jijo James wrote the technical article with inputs from Ebenezer Paul Billy Graham D., Mahalakshmi N., Mohan Kumar T. and Jayapal M.

\section{ACKNOWLedgements}

The authors would like to thank the Management of Tagore Engineering College for providing the laboratory facilities to carry out this investigation. We would also like to thank Mr. M. Sasi Kumar, Laboratory Instructor, Soil Engineering Laboratory for helping out with the testing work.

\section{REFERENCES}

[1] D. N. Little, Handbook for Stabilization of Pavement Subgrades and Base Courses with Lime, Austin, Texas, 1995.

[2] Z. Ji-ru, and C. Xing, "Stabilization of Expansive Soil by Lime and Fly Ash," J. Wuhan Univ. Technol. - Mater. Sci. Ed. vol. 17(4), pp. 73-77, 2002. DOI: https://doi.org/10.1007/BF02838423.

[3] N. K. Sharma, S. K. Swain, and U. C. Sahoo, "Stabilization of a Clayey Soil with Fly Ash and Lime: A Micro Level Investigation," Geotech. Geol. Eng. vol. 30(5), pp. 1197-1205, 2012. DOI: https:// doi.org/10.1007/s10706-012-9532-3.

[4] J. James, S. V. Lakshmi, P. K. Pandian, and S. Aravindan, "Effect of Lime on the Index Properties of Rice Husk Ash Stabilized Soil," Int. J. Appl. Eng. Res. vol. 9(18), pp. 4263-4272, 2014.

[5] A. S. Muntohar, S. Widianti, E. Hartono, and W. Diana, "Engineering Properties of Silty Soil Stabilized with Lime and Rice Husk Ash and Reinforced with Waste Plastic Fiber," J. Mater. Civ. Eng. vol. 25(9), pp. 1260-1270, 2013. DOI: https:// doi.org/10.1061/(ASCE)MT.1943-5533.0000659.

[6] S. Wild, J. M. Kinuthia, G. I. Jones, and D. D. Higgins, "Effects of partial substitution of lime with ground granulated blast furnace slag (GGBS) on the strength properties of lime-stabilised sulphate-bearing clay soils," Eng. Geol. vol. 51(1), pp. 37-53, 1998. DOI: https://doi.org/10.1016/S0013-7952(98)00039-8.

[7] E. Celik, and Z. Nalbantoglu, "Effects of ground granulated blastfurnace slag (GGBS) on the swelling properties of lime-stabilized sulfate-bearing soils," Eng. Geol. vol. 163, pp. 20-25, 2013. DOI: https:// doi.org/10.1016/j.enggeo.2013.05.016.

[8] A. Ghosh, "Compaction Characteristics and Bearing Ratio of Pond Ash Stabilized with Lime and 
Phosphogypsum," J. Mater. Civ. Eng. vol. 22(4), pp. 343-351, 2010. DOI: https://doi.org/10.1061/ (ASCE)MT.1943-5533.0000028.

[9] J.James, and P. K.Pandian, "Effect of Phosphogypsum on the Strength of Lime Stabilized Expansive Soil," Gradevinar, vol. 66(12), pp. 1109-1116, 2014. DOI: https://doi.org/10.14256/JCE.1097.2014.

[10] L. C. Dang, H. Hasan, B. Fatahi, R. Jones, and H. Khabbaz, "Enhancing the Engineering Properties of Expansive Soil Using Bagasse Ash and Hydrated Lime," Int. J. GEOMATE. vol. 11(25), pp. 24472454, 2016.

[11] J. James, and P. K. Pandian, "Valorisation of Sugarcane Bagasse Ash in Manufacture of LimeStabilized Blocks," Slovak J. Civ. Eng. vol. 24(2), pp. 7-15, 2016. DOI: https://doi.org/10.1515/sjce-20160007.

[12] M. N. Rahmat, and N. Ismail, "Sustainable stabilisation of the Lower Oxford Clay by nontraditional binder," Appl. Clay Sci. vol. 52(3), pp. 199-208, 2011. DOI: https://doi.org/10.1016/j. clay.2011.02.011.

[13] J. James, and P. K. Pandian, "A Study on the Early UCC Strength of Stabilized Soil Admixed with Industrial Waste Materials," Int. J. Earth Sci. Eng. vol. 07(03), pp. 1055-1063, 2014.

[14] J. James, and P. K. Pandian, "Geoenvironmental application of sugarcane press mud in lime stabilisation of an expansive soil: a preliminary report," Aust. J. Civ. Eng. vol. 14(2), pp. 114-122, 2016. DOI: https://doi.org/10.1080/14488353.2017. 1316026.

[15] J. James, and P. K. Pandian, "Development of Early Strength of Lime Stabilized Expansive Soil: Effect of Red Mud and Egg Shell Ash," Acta Tech. Corviniensis - Bull. Eng. vol. 9(1), pp. 93-100, 2016.

[16] C. W. Gray, S. J. Dunham, P. G. Dennis, F. J. Zhao, and S. P. Mcgrath. "Field evaluation of in situ remediation of a heavy metal contaminated soil using lime and red-mud," Environ. Pollut. vol. 142(3), pp. 530-539, 2006. DOI: https://doi.org/10.1016/j. envpol.2005.10.017.

[17] J. James, P. K. Pandian, and A. S. Switzer, "Egg Shell Ash as Auxiliary Addendum to Lime Stabilization of an Expansive Soil," J. Solid Waste Technol. Manag. vol. 43(1), pp. 15-25, 2017. DOI: https://doi.org/doi. org/10.5276/JSWTM.2017.15.

[18] J. James, and P. K. Pandian, "Industrial Wastes as Auxiliary Additives to Cement / Lime Stabilization of Soils," Adv. Civ. Eng. vol. 2016(Article ID 1267391), pp. 1-17, 2016. DOI: https://doi. org/10.1155/2016/1267391.

[19] C. Heidrich, H. -J Feuerborn, and A. Weir, "Coal Combustion Products : a Global Perspective," In: World of Coal Ash Conference, Lexington, KY, 2013.

[20] H. Motz, A. Ehrenberg, and D. Mudersbach, "Dry Solidification with heat recovery of ferrous slag," In:
Third International Slag Valorisation Symposium, Leuven, Belgium, 2013.

[21] Central Electricity Authority, "Report on Fly Ash Generation at Coal / Lignite Based Thermal Power Stations and its Utilization in the Country for the Year 2014-15," New Delhi, India, 2015.

[22] FICCI, "Using Steel slag in infrastructure development," Availble in: http://blog.ficci.com/ steel-slag/5291/, 2014.

[23] Y. Huang, and Z. Lin, "Investigation on phosphogypsum-steel slag-granulated blast-furnace slag-limestone cement," Constr. Build. Mater. vol. 24(7), pp. 1296-1301, 2010. DOI: https://doi. org/10.1016/j.conbuildmat.2009.12.006.

[24] M. Chen, M. Zhou, and S. Wu, "Optimization of blended mortars using steel slag sand," J. Wuhan Univ. Technol. Sci. Ed. vol. 22(4), pp. 741-744, 2007. DOI: https://doi.org/10.1007/s11595-006-4741-3.

[25] W. Shen, M. Zhou, W. Ma, J. Hu, and Z. Cai, "Investigation on the application of steel slag-fly ash-phosphogypsum solidified material as road base material.," J. Hazard. Mater. vol. 164(1), pp. 99-104, 2009. DOI: https://doi.org/10.1016/j. jhazmat.2008.07.125.

[26] D.G. Grubb, M. Wazne, S. C. Jagupilla, and N. E. Malasavage, "Beneficial Use of Steel Slag Fines to Immobilize Arsenite and Arsenate: Slag Characterization and Metal Thresholding Studies," J. Hazardous, Toxic Radioact. Waste. vol. 15(3), pp. 130-150, 2011. DOI: https://doi.org/10.1061/ (ASCE)HZ.1944-8376.0000077.

[27] Y. Liang, W. Li, and X. Wang,"Influence of Water Content on Mechanical Properties of Improved Clayey Soil Using Steel Slag," Geotech. Geol. Eng. vol. 31(1), pp. 83-91, 2012. DOI: https://doi. org/10.1007/s10706-012-9564-8.

[28] BIS, IS 2720 Methods of Test For Soils:Part 1 Preparation of Dry Soil Sample for Various Tests, pp. 1-10, 1983

[29] BIS, IS 1498 Classification and Identification of Soils for General Engineering Purposes, pp. 4-24, 1970.

[30] A. A. Nasrizar, K. Ilamparuthi, and M. Muttharam, "Quantitative Models for Strength of Lime Treated Expansive Soil," In: GeoCongress, American Society of Civil Engineers, Oakland, California, US, 2012. DOI: https://doi.org/10.1061/9780784412121.101.

[31] J. L. Eades, and R. E. Grim, "A Quick Test to Determine Lime Requirements for Lime Stabilization," Highw. Res. Rec. vol. 139, pp. 61-72, 1966.

[32] ASTM, D6276 Standard Test Method for Using pH to Estimate the Soil-Lime Proportion Requirement, pp. 1-4, 2006.

[33] M. R. Thompson, "Factors Influencing the Plasticity and Strength of Lime Soil Mixtures," Univ. Illunois Bull. vol. 64(100), pp. 1-19, 1967. 
[34] Y. Bagheri, F. Ahmad, and M. A. M. Ismail, "Strength and mechanical behavior of soil-cement-limerice husk ash (soil-CLR) mixture," Mater. Struct. vol. 47(1-2), pp. 55-66, 2014. DOI: https://doi. org/10.1617/s11527-013-0044-2.

[35] ASTM, ASTM D 5102 Standard Test Method for Unconfined Compressive Strength of Compacted Soil-Lime Mixtures, pp. 1-6, 1996.

[36] S. Bhuvaneshwari, R. G. Robinson, and S. R. Gandhi, "Behaviour of Lime Treated Cured Expansive Soil Composites," Indian Geotech. J. vol. 44(3), pp. 278293, 2013. DOI: https://doi.org/10.1007/s40098013-0081-3.

[37] J. James, P. K. Pandian, K. Deepika, J. M. Venkatesh, V. Manikandan, and P. Manikumaran, "Cement Stabilized Soil Blocks Admixed with Sugarcane Bagasse Ash," J. Eng. vol. 2016(Article ID 7940239), pp. 1-9, 2016.

[38] F. G. Bell, "Lime stabilization of clay minerals and soils," Eng. Geol. vol. 42(4), pp. 223-237, 1996. DOI: https://doi.org/10.1016/0013-7952(96)000282.
[39] A. Muhmed, and D. Wanatowski, "Effect of Lime Stabilisation on the Strength and Microstructure of Clay," IOSR J. Mech. Civ. Eng. vol. 6(3), pp. 87-94, 2013.

[40] M. Dafalla, E. Mutaz, and M. Al-shamrani, "Compressive strength variations of lime-treated expansive soils," In: International Foundations Congress and Equipment Expo, San Antonio, Texas, pp. 1402-1409, 2015. DOI: https:/doi. org/10.1061/9780784479087.126.

[41] K. Rajakumaran, "An Experimental Analysis on Stabilization of Expansive Soil With Steel Slag and Fly Ash," Int. J. Adv. Eng. Technol. vol. 7(6), pp. 1745-1752, 2015. DOI: https://doi.org/10.5121/ ijcsa.2014.4120.

[42] I. Z. Yildirim, M. Prezzi, and H. Santoso, "Use of Soil-Steel Slag-Class-C Fly Ash Mixtures in Subgrade Applications, Publication FHWA/IN/ JTRP-2013/06," West Lafayette, Indiana, 2013. DOI: https://doi.org/10.5703/1288284315188. 
